に、シアン化カリウム $30 〜 140 \gamma$ においてほとえど完全 に留出し定量しうることが判明した。

Table III Determination of $\mathrm{KCN}$ after distillation

\begin{tabular}{cccc}
\hline $\begin{array}{c}\mathrm{KCN} \text { taken } \\
(\gamma)\end{array}$ & $0.0001 \mathrm{M} \mathrm{Hg}\left(\mathrm{NO}_{3}\right)_{2}$ & $\begin{array}{c}\mathrm{KCN} \text { found } \\
(\gamma)\end{array}$ & $\begin{array}{c}\text { Error } \\
(\gamma)\end{array}$ \\
\hline 28.3 & 2.20 & 28.6 & +0.3 \\
$\prime \prime$ & 2.17 & 28.3 & 0 \\
70.8 & 5.42 & 70.6 & -0.2 \\
$\prime \prime$ & 5.32 & 70.1 & -0.7 \\
100.5 & 7.67 & 99.9 & -0.6 \\
$\prime \prime$ & 7.70 & 100.3 & -0.2 \\
143.5 & 11.00 & 143.2 & -0.3 \\
$\prime \prime$ & 10.97 & 142.9 & -0.6 \\
\hline
\end{tabular}

\section{$4 \cdot 2$ 食品中に混入したシアン化カリゥムの定量}

Table III の実験は単純なシアン化カリウム溶液につ いておこなったものであるが，さらに本定量法が裁判化 学的な試料に応用できるかどうか学検討するため, 食パ

Table IV Determination of $\mathrm{KCN}$ in bread after distillation

\begin{tabular}{cccc}
\hline $\begin{array}{c}\mathrm{KCN} \text { taken } \\
(\gamma)\end{array}$ & $0.0001 M \underset{(\mathrm{m} l)}{\mathrm{Hg}\left(\mathrm{NO}_{3}\right)_{2}}$ & $\begin{array}{c}\mathrm{KCN} \text { found } \\
(\gamma)\end{array}$ & $\begin{array}{c}\text { Error } \\
(\gamma)\end{array}$ \\
\hline 72.0 & 5.50 & 71.6 & -0.4 \\
$\prime \prime$ & 5.48 & 71.4 & -0.6 \\
138.0 & 10.54 & 137.3 & -0.7 \\
\hline
\end{tabular}

ン $2 \mathrm{~g}$ にシアン化カリウムを添加したものについて4・1の 方法にしたがって定量を掞こなった。その結果は Table IV に示古.

実験值は理論值よりやや低く出る傾向があるが，本定 量法は十分実用分析として用い得ることが判明した. 食 パンを $5 \mathrm{~g}$ に増量した時は液量 $50 \mathrm{ml}$ ではコルベンの. 内容物が固化して蒸留を妨げ実験值は理論值より低くな った.

\section{交献}

1) 田中善正，山本セツ：本誌，5，440 (1956). is

Volumetric determination of cyanide using cupric diethyldithiocarbamate as an indicator. Yoshimasa TanaKa and Setsu Yamamoto (Faculty of Pharmacy, University of Kumamoto)

A new volumetric determination of micro quantities of cyanide has been investigated. A sample solution containing cyanide ions can be titrated by $0.0001 M$ mercuric nitrate solution with carbon tetrachloride solution of cupric diethyldithiocarbamate as an indicator. At the end point, the brown coloration of carbon tetrachloride layer disappears. The quantitative determination of $30 \sim 140 \gamma$ of potassium cyanide can be made within an error of $\pm 1.3 \gamma$. The presence of halide or organic matter causes an error, but after the steam distillation cyanide can be determined without any disturbance.

(Received June 18, 1959)

\title{
ジフェニルカルバチッド水銀紙を用いる 微量シアンイオンの検出および定量
}

田中 善正，山本 セツ*

青紫色のジフェニルカルバチッド水銀紙は中性ないしアルカリ性でシアンイオンによって赤色虽す る. 試料觉ミクロガス発生器にとり重炭酸ナトリウムを加えて加熱し, 発生するガス觉水酸化ナトリウ ム溶液で湿した試験紙に接触させると，シアンイオンの存在で試験紙が赤変し $0.05 \gamma$ のシアンイオン まで検出するてとができた．硫化物は類似の反応を呈するが硝酸力ドミウムを加えるとその障害が除去 できた。またての試験紙の変色した部分の長さはシアンイオンの量に比例し，その長さをはかることに より簡易に 1〜10 rのシアンイオンを定量するととができた. 本定量法は硫化物，フェリシァン化物， ヨウ化物の共存で誤差を生じたが前二者は硝酸カドミウムの添加によって後者は蒸留によって障害觉除 くことができた。また本法は裁判化学的な試料についても実施することができた。 


\section{1 緒言}

従来, 裁判化学上ではシアンイオンの検出にグアヤク 試験紙またはベンジジン酢酸銅試験紙などが用いられて いるが1，著者らはジフェニルカルバチッド水銀紙を同 じ目的に用いてさらに良好な結果が得られることを知っ た・すなわちジフェルカルバチッドは中性ないし弱酸 性で水銀イオンによって青紫色の沈殿を生ずるが，この 沈殿を口紙内に沈着させた試験紙它つくり，こ机に中性 ないしアルカリ性でシアンイオンを作用させると試験紙 の青紫色が赫变することを見いだした。この变色はきわ めて認めやすく, かつ非常に鋭敏で $0.05 \gamma$ のシアンイ オンまで検出することができた。ささらに著者らはこの試 験紙の変色した部分の長さがシアンイオンの量に比例す ること它知り，その唇さをはかることによって簡易に微 量のシアンイオン定定量することができた，試駘紙変色 の反応機構は，まず試験紙にはジフェニルカルバチッド と水銀イオンが反応してできたジフェニルカルバゾーン の水銀塩が存在し，こ秃にシアンイオンを働かせると水 銀はジフェニルカルバゾーンより離机てシアン水銀とな り，赤色のジフェニルカルバゾーンのアルカリ金属塩を 遊離するためと考えられる。したがってはじめからジフ ェニルカルバゾーンを用いてつくった試騃紙も同様の反 応を示したが，ジフェニルカルバチッドを用いてつくっ た試験紙の方が変色も見やすくすぐ机ておった。したが って以後の実験はすべてジフェニルカルバチッドより調 製した試験紙を用い，その名称も反応機構から考えれば やや不適当かと思わ机るが，ジフェニルカルバチッド水 銀紙としておいた。

\section{2 試験紙の調製}

ジフニニルカルバチッド $0.1 \mathrm{~g}$ 佟アセトン $100 \mathrm{ml}$ に 溶解し，この溶液に口紙（東洋沪紙 No. 2) を浸し乾燥 した。ついでこの口紙を $0.5 \%$ 硝酸第二水銀溶液（硝酸 を加えて弱酸性となし加水分解觉防ぐ）に浸して十分青 紫色に発色させたのち，よく水洗し暗所に風乾した。定 量用の目的には均一な試験紙を調製するよう細心の注意 をした、試験紙は空気酸化を受けて徐々に退色するが, 褐色瓶中に密栓して貯えると定量用で $1 \sim 2$ 力月，定性 用で 6 力月位まで支障なく使用することができた。

\section{3 試験紙と各イオンとの呈色反応}

本試験紙は中性ないしアルカリ性でシアンイオンによ って赤色を呈するが，その他水銀と結合して難溶性の塩 あるいは非解離性の塭をつくるイオンによっても類似
の反応を呈した・本試験紙によって呈色するイオンを Table I に示す. Table I はこれらイオンのカリウ ムもしくはナトリウム塩の水溶液を 1 滴試験紙上に滴加 して観察した場合であって，Table I に示した鋭敏度 汇この方法で認めうる 1 滴中の最小量を $\gamma$ 単估で表わし たものである。

Table I Color development with mercuric diphenylcarbazide paper

\begin{tabular}{lcc}
\hline Ion & Color & $\begin{array}{r}\text { Limit of identification } \\
\text { in } 0.05 \mathrm{ml}\end{array}$ \\
\hline $\mathrm{CN}^{-}$ & pink & 0.25 \\
$\mathrm{Br}^{-}$ & $\prime \prime$ & 5 \\
$\mathrm{I}^{-}$ & $\prime \prime$ & 2.5 \\
$\mathrm{SCN}^{-}$ & $\prime \prime$ & 5 \\
$\mathrm{~S}^{2-}$ & $\prime \prime$ & 5 \\
$\mathrm{~S}_{2} \mathrm{O}_{3}{ }^{2-}$ & $" \prime$ & 1 \\
$\mathrm{Fe}^{-}(\mathrm{CN})_{6}{ }^{3-}$ & greenish yellow & 50 \\
$\mathrm{CrO}_{4}{ }^{2-}$ & yellowish brown & 500 \\
\hline
\end{tabular}

4 定性分析法

試料溶液を直接試験紙に滴加して検出する方法恃 3 で 述べたように障害反応が多く，簡単な試料の場合以外は 実用となし得ない。著者らはこれら障害イオンの共存で シアンイオンを検出する方法としてミクロガス発生器に 試料をとり，重炭酸ナトリウムを加えて加熱しシアンイ オンをシアン化水素として留出分離させ検出する方法を 試夕た。分析装置は Fig. 1 に示したるクロガス発生器 を用い，試験紙は $1.5 \times 30 \mathrm{~mm}$ に切断したものを $3 \%$ 水 酸化ナトリウム液で湿したのち上部に挿入した。

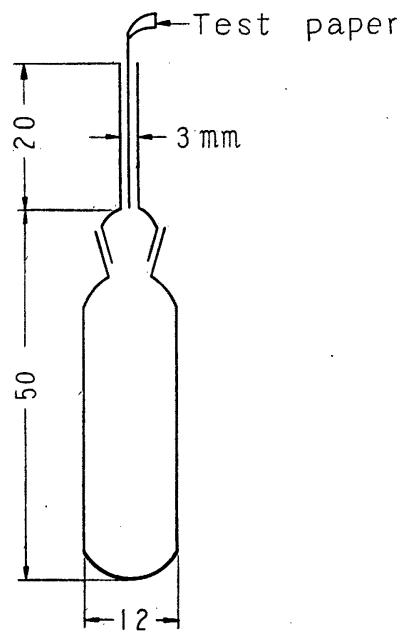

Fig. 1 Apparatus for qualitative analysis 
分析方法は試料溶液 $0.5 \mathrm{ml}$ を取り, 炭酸水素ナトリ ウム $0.1 \mathrm{~g}$ を加え, ミクロバーナーで徐々に加熱し, 試 験紙の変色をしらべた. シアンイオンが存在すればシア ン化水素は炭酸ガスとともに追いだされて上部に挿入し た試験紙は下部より順次赤変した。本法によるシアンイ オンの検出はきわめて鋭敏であって $0.5 \mathrm{ml}$ 中に $0.05 \gamma$ のシアンイオンまで検出することができた。 また本法に よれば Table I にかかげた障害イオンの影響も少な く, 臭素, ヨウ素, 硫シアン, チオ硫酸の各イオンは $0.5 \mathrm{ml}$ 中に $25 \mathrm{mg}$ まで存在しても試験紙を赤変させな かった・ただ硫化物は $2.5 \gamma$ 以上存在すれば同様の反応 を示し障害となった。本法を裁判化学の試料に適用する 場合, 試料の腐敗によって生ずる硫化水素がシアンと類 似反応を呈することは注意を要する・硫化物の共存でシ アンを検出するに流化物に対応する量以上の硝酸力ド そウム溶液学加えてから本法をおこなうと, 硫化物によ る影響を全く除去することができ，シアンイオン検出の 鋭敏度は硝酸カドミウムの添加によっても変化がなかっ た.

\section{5 定量分析法}

試験紙によって簡易にシアン化水素を定量する方法は すでに種々のものが発表されている2゙. たとえばベンチ ジン酶酸銅試験紙，メチルオレンジ昇录試験紙，ピクリ ン酸試験紙，グアヤク銅試験紙，フェノールフタリン試 験紙などが用いられている．著者らはジフェニルカルバ チッド水銀紙を用いて簡易にかつ正確にシアンイオンを 定量することができた。

\section{$5 \cdot 1$ 分析装置および定量方法}

定量に用いた装置は Fig. 2 に示したミクロガス発生 器だ，小試験管とガス導出管を附けたゴム栓とからでき ている.

試験紙は $3 \times 60 \mathrm{~mm}$ 亿正確に切断して $3 \%$ 水酸化ナト リウム溶液に浸し，余分の液は口紙に軽く挾えで除いた のち,ガス導出管に挿入した・定量方法は試料 $1 \mathrm{ml}$ を小 試験管にとり炭酸水素ナトリウム $0.3 \mathrm{~g}$ 孛加え栓をして ミクロバーナーで徐々に加熱した. シアン化水素は炭酸 ガスとともにガス導出管に入り試験紙は下部より順次赤 变した。液が沸騰し始めれば加熱を中止して試験紙を取 りだし, 変色部分の長さをノギスで測定し, あらかじめ 作製した検量線と比較し含量を決定した。变色部分の境 界では長さ 2 ～3 mm にわたって赤が順次薄れてゆくが, このぼやけた部分の中点を変色部分の端ときめ, それま での長さをもって変色帯の長さとした. ガス導出管は分

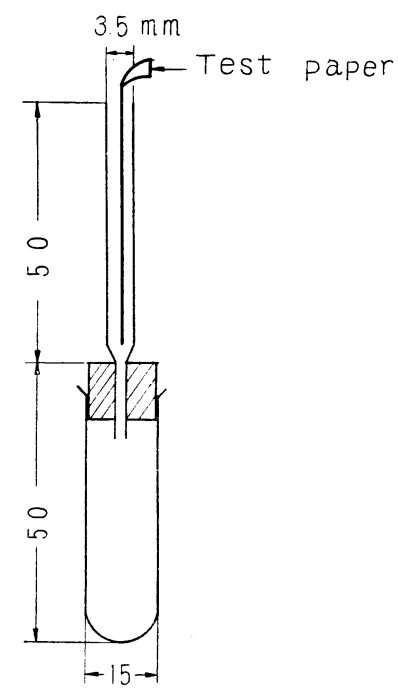

Fig. 2 Apparatus for quantitative analysis

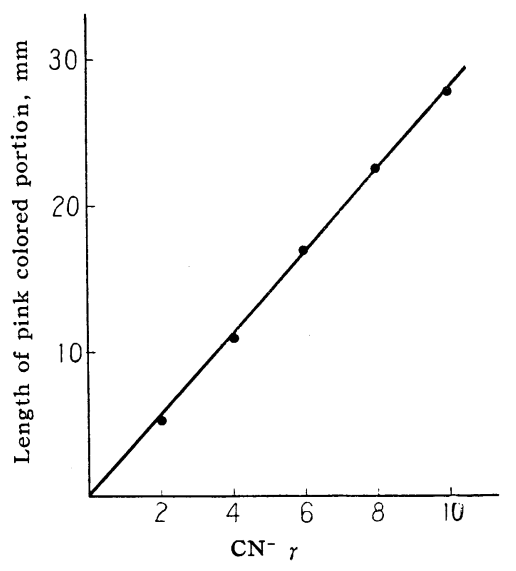

Fig. 3 Calibration curve

析のたびごとに必ず乾燥したもの学用いた。検量線注 Fig. 3 に示したとおりであって, シアンイオンの量注 変色帯の長さに比例した.

変色帯の長さにおよぼす炭酸水素ナトリウム量の影響 については, 同一量のシアンイオンを取り炭酸水素ナト リウム量を種々变化させて実験した結果, 炭酸水素ナト リウムが少ない時は炭酸水素ナトリウム量の増加ととも に変色带の長さも増したが, 炭酸水素ナトリウムが $0.3 \mathrm{~g}$ 以上になるとその量に無関係に一定の変色带の長さを示 した。したがって上述のように炭酸水素ナトリウムは $0.3 \mathrm{~g}$ とした．試験紙を浸す水酸化ナトリウム溶液の濃 度は直接変色帯の長さと関係が無かった。 


\section{$5 \cdot 2$ 定量結果}

同一量のシアンイオンを取って $5 \cdot 1$ の方法にしたがい 定量をおこなっても，変色帯の長さは調製時の異なった 試験紙では異なった值を示した。したがって一連の実験 には必ず同時に調製した 試験紙を用いなければならな い. また試験紙は均一なものをつくるため細心の注意が 必要であり，通常に作製した試験紙の周辺部分は不均一 なので切り捨て中央部のみを用いた。また試験紙を切断 する時はその幅を正確に一定にしなければならぬ。また 口紙の質が定量結果に大きな影響を与え，同じ東洋沪紙 の No. 2 でも入手経路の異なった幾種類かについて試 験紙を調製したところその良否がまちまちであった。し たがって著者らはもっとも良好な結果を示した口紙をや や多量入手して試験紙調製用とした. 東洋沪紙のNo. 5 B No. 51 についても試験したが No. 2 よりかえつ て悪かったので用いなかった，良好な試験紙を用いた場 合はくりかえして同一量のシアンを定量した際実験值が かなりよく一致した、種々のシアン量について定量し た結果は Table II に示したとおりであって，2１0 のシアンイオンが最大 $0.5 \gamma$ の誤差で簡易に定量でき た.

Table II Determination of cyanide

\begin{tabular}{|c|c|c|c|}
\hline $\begin{array}{c}\mathrm{CN}^{-} \text {taken } \\
(\gamma)\end{array}$ & $\begin{array}{l}\text { Length of pink } \\
\text { colored portion }(\mathrm{mm})\end{array}$ & $\begin{array}{c}\mathrm{CN}^{-} \text {found } \\
(\gamma)\end{array}$ & $\begin{array}{c}\text { Error } \\
(\gamma)\end{array}$ \\
\hline 2.0 & 4.4 & 1.6 & -0.4 \\
\hline "I & 5.6 & 2.0 & 0 \\
\hline "I & 5.7 & 2.1 & +0.1 \\
\hline 4.0 & 10.6 & 3.9 & -0.1 \\
\hline "I & 10.5 & 3.8 & -0.2 \\
\hline "I & 11.3 & 4.1 & +0.1 \\
\hline 6.0 & 17.2 & 6.3 & +0.3 \\
\hline "I & 16.5 & 6.0 & 0 \\
\hline "I & 17.1 & 6.2 & +0.2 \\
\hline 8.0 & 23.4 & 8.5 & +0.5 \\
\hline "I & 21.2 & 7.7 & -0.3 \\
\hline "I & 21.6 & 7.9 & -0.1 \\
\hline 10.0 & 27.4 & 10.0 & 0 \\
\hline " & 27.2 & 9.9 & -0.1 \\
\hline "I & 27.8 & 10.1 & +0.1 \\
\hline
\end{tabular}

\section{$5 \cdot 3$ 共存イオンの影響}

他種イオンの共存で $10.0 \gamma$ のシアンイオンを定量し た結果を Table III に示す.

すなわち塩素, 臭素, 硫シアン，チオ硫酸，フェロシア ンの各イオンは多量共存しても定量結果に影響をあたえ ないが, ヨウ素, イオウ, フェリシアンの各イオンの共存 では定量值が過大になった. 4 でのべた定性分析の場合
Table III Determination of cyanide in the presence of other ions

\begin{tabular}{lcccc}
\hline Ion & $(\mathrm{mg})$ & $\begin{array}{l}\text { Length of pink } \\
\text { colored portion }(\mathrm{mm})\end{array}$ & $\begin{array}{c}\mathrm{CN}^{-} \text {found } \\
(\gamma)\end{array}$ & $\begin{array}{c}\text { Error } \\
(\gamma)\end{array}$ \\
\hline $\mathrm{Cl}^{-}$ & 25 & 27.3 & 10.0 & 0 \\
$\mathrm{Br}^{-}$ & 25 & 28.7 & 10.5 & +0.5 \\
$\prime \prime$ & 10 & 27.9 & 10.2 & +0.2 \\
& & & & +3.6 \\
$\mathrm{I}^{-}$ & 25 & 37.4 & 13.6 & +1.6 \\
$\prime \prime$ & 5 & 31.9 & 11.6 & +1.1 \\
$\prime \prime$ & 1 & 30.3 & 11.1 & +1.1 \\
$\prime \prime$ & 0.5 & 28.5 & 10.4 & +0.4 \\
& & 27.3 & 10.0 & 0 \\
$\mathrm{SCN}^{-}$ & 25 & 27.4 & 10.0 & 0 \\
$\mathrm{~S}_{2} \mathrm{O}_{3}{ }^{2-}$ & 25 & 38.6 & 14.1 & +4.1 \\
$\mathrm{~S}^{2-}$ & 0.1 & 33.5 & 12.2 & +2.2 \\
$\mathrm{Fe}(\mathrm{CN})_{6}{ }^{3-}$ & 25 & 27.8 & 10.1 & +0.1 \\
$\mathrm{Fe}(\mathrm{CN})_{6}{ }^{4-}$ & 25 & & & \\
\hline
\end{tabular}

$\mathrm{CN}^{-}$taken $10.0 \mathrm{r}$

は障害イオンは硫化物のみであったが，定量の場合には 炭酸水素ナトリウム量および加熱盜度の違いのためヨウ 素, フェリシアンも障害するものと考えられる. 裁判化 学の試料では腐敗によって生ずる硫化水素の影響に注意 しなければならない。

$5 \cdot 4$ 硫化物および フェリシアン化物共存における シ. アンイオンの定量

硫化物およびフェリシアン化物によるプラスの誤差は これに硝酸カドミウムを加えることにより除くことがで きた. シアンイオン $10.0 \gamma$ をとり障害イオン $5 \mathrm{mg}$ の共存において $20 \mathrm{mg}$ のカドミウムイオンを添加後, $5 \cdot 1$ の方法にしたがい定量した結果を Table IV に示 के.

Table IV Determination of cyanide by an addition of $\mathrm{Cd}\left(\mathrm{NO}_{3}\right)_{2}$

\begin{tabular}{lcccc}
\hline \hline Ion & $(\mathrm{mg})$ & $\begin{array}{l}\text { Length of pink } \\
\text { colored portion }(\mathrm{mm})\end{array}$ & $\begin{array}{c}\mathrm{CN}^{-} \text {found } \\
(\gamma)\end{array}$ & $\begin{array}{c}\text { Error } \\
(\gamma)\end{array}$ \\
\hline $\mathrm{S}^{2-}$ & 5 & 27.8 & 10.3 & +0.3 \\
& $\prime \prime$ & 27.6 & 10.2 & +0.2 \\
$\mathrm{Fe}(\mathrm{CN}){ }_{6}{ }^{3-}$ & 5 & 27.0 & 9.9 & -0.1 \\
& $\prime \prime$. & 27.1 & 9.9 & -0.1 \\
\hline
\end{tabular}

\section{$5 \cdot 5 \exists$ ヨ化物共存におけるシアンイオンの定量}

微量のヨウ素イオンの共存は本法の障害とならない が， $1 \mathrm{mg}$ 以上共存すれば定量值が過大になり，この影 響は硝酸カドミウムの添加によっても防ぐことができな かった、したがって著者らは Fig. 4 に示したミク口蒸 留装置を用い試料を酒石酸酸性にして蒸留した留液につ いて定量をおこないヨウ素イオンの影響を除くことがで きた. 受器には $0.5 \mathrm{ml}$ の蒸留水に $20 \%$ 炭酸ナトリウ 


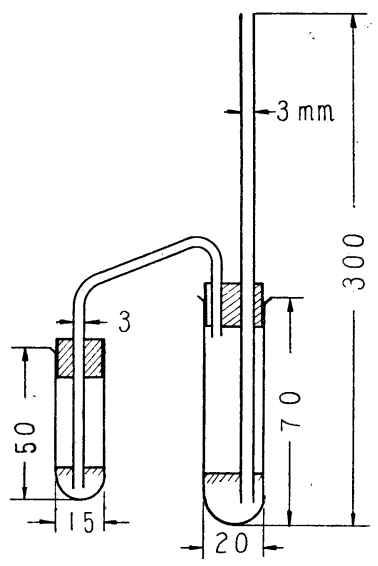

Fig. 4 Microdistillation apparatus

ム溶液 1 滴を加えたものを入れた。受器はFig. 2 の定 量装㯰の小試験管であって蒸留終了後移しかえることな くただちに定量をおこなうことができる。

多量のヨウ䋕イオンの共存で蒸留法によりシアンイオ ンを定量した結果を Table V に示す。

Table $\mathrm{V}$ Determination of cyanide after distillation

\begin{tabular}{ccccc}
\hline $\begin{array}{c}\mathrm{I}^{-} \\
(\mathrm{mg})\end{array}$ & $\begin{array}{c}\mathrm{CN}^{-} \text {taken } \\
(\gamma)\end{array}$ & $\begin{array}{c}\text { Length of pink } \\
\text { colored portion }(\mathrm{mm})\end{array}$ & $\begin{array}{c}\mathrm{CN}^{-} \text {found } \\
(\gamma)\end{array}$ & $\begin{array}{c}\text { Error } \\
(\gamma)\end{array}$ \\
\hline 25 & 10.0 & 28.7 & 10.5 & +0.5 \\
$\prime \prime$ & $\prime \prime$ & 28.0 & 10.2 & +0.2 \\
\hline
\end{tabular}

Table VI Determination of cyanide contained in bread

\begin{tabular}{cccc}
\hline $\begin{array}{c}\mathrm{CN}^{-} \text {taken } \\
(\gamma)\end{array}$ & $\begin{array}{c}\text { Length of pink } \\
\text { colored portion }(\mathrm{mm})\end{array}$ & $\begin{array}{c}\mathrm{CN}^{-} \text {found } \\
(\gamma)\end{array}$ & $\begin{array}{c}\text { Error } \\
(\gamma)\end{array}$ \\
\hline 10.0 & 26.4 & 9.6 & -0.4 \\
$\prime \prime$ & 27.7 & 10.1 & +0.1 \\
$\prime \prime$ & 27.1 & 9.9 & -0.1 \\
\hline
\end{tabular}

\section{$5 \cdot 6$ 有機物共存におけるシアンイオンの定量}

著者らは本定量法が裁判化学の試料机てもおてな い得るかどうかをしらべるため，パンを水とともにミキ サーにかけ乳状液としたものにシアンイオンを添加して $5 \cdot 1$ の方法にしたがい定量をおこなったが，Table VI に示したように障害なく定量することができた。

ただしパン以外の食品たとえば牛乳などの共存の場合 には，炭酸水素ナトリウムを加えて加熱する際に消光に くい泡が盛えに出て定量が困難になることがあった。こ のような場合には Fig. 4 のミク口蒸留装置を用いヨウ 素イオン共存の場合と同じように酒石酸酸性で蒸留した のち，留液について定量空打こならこ支障なく定量する ことができた。

(昭和 34 年: 4 月, 日本薬学会総会で講演)

$$
\text { 交献 }
$$

1）塚元久雄, 奥井誠一：“裁判化学”, 20 (1958), (南山堂).

2) 日本薬学会編：“衛生武験法註解”，655(1956), (金原出版).

$$
\text { is }
$$

Detection and determination of cyanide using mercuric diphenylcarbazide paper. Yoshimasa TANAKA and Setsu Yamamoto (Faculty of Pharmacy, University of Kumamoto)

The purple color of mercuric diphenylcarbazide paper changed to pink by cyanide ions in a neutral or alkaline solution. The test paper immersed in a sodium hydroxide solution was hung at the top of an apparatus for detection of minute quantities of gas. To a sample solution placed in the apparatus was added sodium bicarbonate and the resulting mixture was warmed on a micro flame. Pink color appeared if cyanide is present. Even $0.05 \gamma$ of cyanide was detected. As the length of pink colored portion of the test paper was proportional to the amount of cyanide, quantitative determination of $2 \sim 10 \gamma$ of cyanide was made within an error of $\pm 0.5 \gamma$. The error caused by the presence of sulfide or ferricyanide was avoided by an addition of cadmium nitrate to the sample solution. When iodide was present in a sample, cyanide could be determined without disturbance after separating it by distillation.

(Received July 20, 1959) 